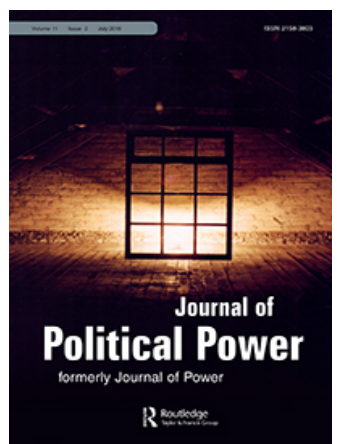

Journal of Political Power

\title{
Authority as epistemic capital
}

\section{Pertti Alasuutari}

To cite this article: Pertti Alasuutari (2018) Authority as epistemic capital, Journal of Political Power, 11:2, 165-190, DOI: 10.1080/2158379X.2018.1468151

To link to this article: https://doi.org/10.1080/2158379X.2018.1468151
(c) 2018 The Author. Published by Informa UK Limited, trading as Taylor \& Francis Group.

曲 Published online: 03 May 2018.

\section{Submit your article to this journal}

\section{Џll Article views: 102}

Q View related articles $\square$

View Crossmark data $\nearrow$ 


\title{
Authority as epistemic capital
}

\author{
Pertti Alasuutari \\ Faculty of Social Sciences, University of Tampere, Tampere, Finland
}

\begin{abstract}
The article proposes that authority denotes an actor's appeals or other references to objects or facts that she expects others to respect or fear. The paper identifies four types of authority: capacity-based, ontological, moral, and charismatic. That is, authority can be built on the assumption that an actor is capable of accomplishing things; on expertise or respected accounts of reality; on deference to principles; and on extraordinary awe attached to an organization or individual. Such authority can be called epistemic capital. Those who are more successful in piling up epistemic capital behind their projects have more influence on others' conduct.
\end{abstract}

\section{KEYWORDS}

Authority; power; epistemic work; governance; world society; Weber

\section{Introduction}

A standard starting point for theorization of power is to consider a real or imagined community, society or organization and to ask who has power in it and on what grounds. Weber's classical treatment of power and authority in a society or organization is a prime example. The community power debate, which has set the coordinates for generations of theorists (Clegg 1976, Dowding 2011), is another case in point. In it, 'elitists' argued that the communities studied had a ruling elite, whereas 'pluralists' stressed that several 'cliques' had influence in different issue areas. Yet both sides of the debate shared the vantage point that power denotes a hierarchical feature of a community: a pyramid or a multi-peak profile. Discussants also pointed out that power has different 'faces,' for instance that those exercising power can do it by acting on people's consciousness of their real interests (Lukes 2005), but the focus of mainstream theorization has remained in considering power as a hierarchical feature of a community or society. ${ }^{1}$

Taking into account the role of language in the social world poses a challenge to this framing of power relations. As Potter and Wetherell put it when characterizing the points made in discursive research: 'Social texts do not merely reflect or mirror objects, events and categories pre-existing in the social and natural world. Rather, they actively construct a version of those things. They do not just describe things; they do things. And being active, they have social and political implications' (1987, p. 6). The challenge is to define the object of study in a way that does not involve the analyst in the very strategies 
of dominance and influence that one is supposed to reveal. The mainstream approach is problematic in this respect.

From this perspective it is, for instance, questionable to consider the existence of a hierarchy of power as a starting point, because it hides from view the performative aspect of power - that is, the fact that presenting and describing an actor as powerful is part of the strategies by which authority is constructed. Kings and emperors have always built impressive palaces and made sure that people who face rulers are physically placed in a position that makes them feel inferior to the rulers. Similarly, in work organizations, task descriptions and classifications of job titles contribute to legitimating income differences, for instance gender inequality. Hence men who have the same level of education but a bigger salary have terms such as 'higher,' 'principal' or 'director' in their title and job description, regardless of actual chains of command (Kinnunen 2001).

Talking about power relations in a society or organization is also tricky in that it carries with it the assumption of a community as an independent social system that defines each actor's position in it. I do not mean to argue that theorists have not referred to the outside world. In the community power debate, for instance, participants talked about 'corporate lawyers,' 'businesspeople,' and 'capitalists' as key players in the local power game. However, the idea of power as a hierarchical system within a community ignores the fact that talking about such actor roles and identities refers to concepts and beliefs of the surrounding social world, and that actors' authority depends and leans on those notions. For instance, lawyers build their influence on their expertise in, say, how to apply nationally and globally acknowledged legal principles to an individual case.

Furthermore, the standard vantage point of denoting power as a hierarchical aspect of a community leads to treating power relations as fixed and settled. The presumption that there are roles such as authorities and subalterns in a community easily overlooks constant contestation of the actors' attempts and claims of dominance, as well as strategies of resistance, non-compliance and opposition, which, as Coleman stresses, are 'built into any system of legitimate authority' (Coleman 1997, p. 40). As shown in the vast scholarship on discourse theory (Torfing 1999, van Dijk 1993, e.g. Fairclough 1993, 2003, Wetherell et al. 2001), these actors claim, appeal to, and challenge authority through using discourses that construct versions of reality and the situation at hand. The challenge is to develop a theory of power and authority that accounts for these discursive strategies.

As a solution to these problems in mainstream approaches to power, rather than presupposing a community with a power structure, I suggest we focus on identifying the strategies by which actors aim to influence others' conduct and thus advance their own goals. From a societal perspective, these strategies have been characterized as different techniques and forms of knowledge that seek to shape people's conduct by acting upon their aspirations, interests and beliefs (Dean 1999, p. 11, Foucault 1991, Inda 2005). Such epistemic work focuses on three aspects of the social world: people's understandings of the ontology of the environment, their identifications, and their conceptions of what is good or desirable (Alasuutari and Qadir 2014, 2016). Constructing and utilizing authoritative actors or things is one way of doing it, and this article aims to form a typology of different forms of authority. Hence, the theory of power and authority built here resembles Weber's classic treatment in that he, too, talked about different types of authority. 
The differences between Weber's theory and the one presented here, however, are significant. For one thing, in the Weberian tradition, authority is distinguished from power, which denotes an actor's ability to carry out his or her will despite resistance, whatever the means, whereas authority signifies legitimate domination: the ability of a person within an organization to give commands which others are likely to obey (Weber 1978, p. 53). Here, instead, power is treated as a concept that refers to the fact that people aspire to rule and control others, whereas authority denotes a means with which it is done: in the attempt to affect others' conduct, an actor appeals or otherwise calls attention to persons, organizations or things that she expects others to respect or fear. Thus, here authority signifies anything that actors use to affect others; it denotes the recognition among the actors of someone or something being worth taking into account when considering one's own conduct. That is, actors may present themselves as powerful or claim authority for themselves, but they may as well make use of authorities and authoritative principles, thus struggling for a hegemonic conception of the situation that significantly affects others' views and behavior. This does not mean that we only talk about subtle means of persuasion by which to get others' consent; in these games of power people can also resort to threats and acts of violence and other means of coercion to get their message through. To use a well-known expression, actors can make an offer that others can't refuse. This means that authorities are not necessarily liked or admired; rulers can be authoritarian and authoritative facts about the environment can be unpleasant.

The theory of authority advocated here stresses that authority is always relational (Emirbayer 1997, Selg 2016a, 2016b): someone or something is authoritative only if people recognize its authority and treat it as such by, for instance, referring to it as a fact when proposing or deciding how to act. Similarly, Foucault's view of power has been interpreted to mean that power is an 'internal relation,' similar to that between husband and wife (Kusch 1991). In such a relationship, each actor could not be thought of without the other ones; the whole constitutes the parts that comprise it. This does not mean that all actors in a network of power relations are equally powerful, but it does mean that power also sets conditions on and affects the identities of those who hold power, and that dominance is dependent on actors' conceptions of themselves and of the whole state of affairs. Related to that, Foucault also stressed that people's conceptions of power are an essential element of the strategies through which we are governed and, as an instance of this, the prevalent notion of power as only comprising a hierarchical chain of command helps to hide from sight subtle strategies through which power also works (1980, p. 85-86). ${ }^{2}$

In affecting others' understanding and behavior, actors use various strategies, although it is important to stress that the term strategy does not necessarily denote conscious calculation; actors' strategies are often intuitive, and their rationality is culture-bound. As discussed in the example above, one strategy is to create and utilize the assumption that an actor is capable of accomplishing things, such as using incentives, punishments, or physical force. This can be called capacity-based authority. Another strategy is to construct or appeal to renowned actors and their accounts of reality, for instance to expert knowledge. This can be called ontological authority. The third strategy is to employ prevalent conceptions of important persons, organizations, texts or principles that allegedly define individual rights and duties. For instance, the 
law and local regulations define individuals' positions within an organization. Let us call this moral authority. Finally, actors may create or utilize extraordinary awe attached to an organization or individual, for instance a famous political or religious leader. This can be called charismatic authority.

Rather than a hierarchical position that allows one to give commands (Weber 1978), we should think of this kind of authority as cumulative: how much bearing actors have on others' conduct varies from marginal to substantial. By building, utilizing and combining different types of authority, actors aim to accumulate their influence on others. In that sense, authority can be called epistemic capital: it is an accumulation of different kinds of 'assets' by which actors ascertain the social world and the situation at hand. When discussing actors' attempts to influence others' conduct, I talk about epistemic capital because it functions through knowledge and its validation. Those who are more successful in piling up epistemic capital behind their projects have more influence on others' conduct.

This approach is close to Parsons' (1963a, 1963b) theory of power as a circulating medium, analogous to money. Some other theorists have also likened the foundations of social order to money. Perhaps the most well-known scholar is Bourdieu, whose theorization of the social world builds on identifying different forms of capital. He, for instance, talks about symbolic capital (Bourdieu and Nice 1977, Bourdieu 1989). Similarly, Putnam and others $(1993,2000)$ talk about social capital, the amount of which is a key feature of a community.

In their persuasion work, actors are eclectic in accumulating epistemic capital behind their projects: they may use all forms of influence from intimidation and incentives to referencing moral principles to influence others' conduct. But regardless of individual differences, all these strategies work upon others' understanding of the world and of the situation at hand. Hence, governance operates through epistemic work in that actors work upon knowledge (in a broad sense of the concept) and its validation. This work focuses on three aspects: what are the facts; what is possible and what not; and what is acceptable or desirable (Alasuutari and Qadir 2014). Besides, how seriously actors are taken depends on how powerful they are believed to be, which is why appealing to emotions, impression management and utilization of prevalent notions of power are an important part of the game.

My proposal to approach power from the perspective of persuasive force does not mean that we need to discard considerations of hierarchical relations in organizations, for instance those between political leaders and citizens. From such a perspective, to cite Reed (2017), we can indeed conceive of power as the ability 'to be able to send someone to act on your behalf [...] and to bind that person to pursue your project.' However, this view of power does not elaborate on the strategies by which actors aim to increase their persuasive force and hence help to explain situations in which all parties affect others' choices, moves and positions. Such a state of affairs is particularly characteristic of networks, 'flat' organizations, and governance based on incentives that aim to move a majority of people in a preferred direction, without anyone giving orders or sending others on their behalf. To capture power games in conflictual situations, we need a broader conception and new vocabulary of power and authority as epistemic capital.

In what follows, I will discuss the shortcomings of the hierarchical view of power, and how the theory developed here overcomes them. Then, I will unpack the four types 
of authority mentioned above. By way of conclusion, I discuss the implications of this theory of authority.

\section{The limits of the hierarchical view of power}

The mainstream theorization and scholarship on power is dominated by views that deal with power and authority as a social hierarchy within a community or social organization. For example, the community power debate, which set the scene for all central issues that continue to be discussed and debated in mainstream analyses of power (Dowding 2011), focused entirely on disagreements on the features and bases of the power structure in a community or society. From Hunter's (1953) and Mills' (1956) community studies to Lukes' (2005) influential synthesis, all the way to commentaries on his theory on the three faces of power, the participants in this lengthy discussion conceive of power as an aspect of an organization or society. Arendt puts this conviction succinctly by noting that power is inherent in the very existence of political communities; it 'springs up whenever people get together and act in concert' (1970, p. 52). This starting point means that the existence of a 'pecking order,' with some individuals having power over others, is taken for granted. Consequently, the question of power becomes a question of who has power in a community and what are its bases. Struggle and strife for dominance and influence tends to be ruled outside the discussion; it is assumed that the battle has been settled. The actors who are outside such a power structure or chain of command are ignored, or their fight for supremacy is not discussed in terms of power.

Reed's (2017) theory of power appears to differ from the mainstream view in that he also mentions those who are outside a hierarchy of power. According to him, power relations comprise three kinds of agents: rectors, who recruit and control allies to pursue their project, actors, who take up rector's project, and others, who are either objects, enemies, or ignorant outsiders. Yet Reed's fascinating terminology is similar to other theories in that, for him also, power depicts chains that involve rectors and actors.

In all, except for some critical voices against the hierarchical view (see Coleman 1997), theories of power and authority tend to take a hierarchy for granted. The self-evident focus is on power as something that wins individuals' resistance and gets them to do something they would not otherwise do (Dahl 1957, p. 202-203) and on domination as 'the probability that a command with a given specific content will be obeyed by a given group of persons' (Weber 1978, p. 53). These and similar definitions of power and authority do not exclude struggle and resistance, but they emphasize a hierarchy in that they assume that a person or a power elite has 'gained the upper hand' in one or several issue areas, which is considered as a criterion for power.

Stemming from Weber, this tradition of talking about power as a hierarchy makes sense when one wants to explain the basic structures of territorial states. According to Weber's story line, empires are built on military force used to conquer a territory and subjugate its population under its rule. But, this story goes, soon social order in that territory is secured also by rules, the observation of which is expected of the population and monitored by the administrative staff. Hence, state formation comprises a monopoly of violence complemented with rules that draw their legitimation from tradition, rationality, or charismatic leadership. A key feature of the state is that it is a compulsory organization with a territorial basis: 
It possesses an administrative and legal order subject to change by legislation, to which the organized activities of the administrative staff, which are also controlled by regulations, are oriented. This system of order claims binding authority, not only over the members of the state, the citizens, most of whom have obtained membership by birth, but also to a very large extent over all action taking place in the area of its jurisdiction. (Weber 1978, p. 56)

According to Weber's theory, the state's domination over the population rests on actual use or threat of force, and on the state's claim to monopolize legitimate coercion by violence. Thus, to use Weber's (1978, p. 56) example, the right of a father to discipline his children is considered legitimate only if permitted by the state in legislation.

This view of power and authority works well in legalistic and bureaucratic contexts. The conceptual system presumes a polity, e.g. a nation-state, as a social organization separate from other polities, making it difficult to account for cross-border influences and interdependencies. The methodological statism (Chernilo 2006, 2008) characteristic of such theorization of power is evident also in the fact that, again following Weber, authority is routinely defined as somehow legitimated domination. The link to judicial vocabulary is so tight that the word which refers to a legal basis is used as a generic term for acceptance or consent. Similarly, Weber chose to depict legitimate domination as authority - a word that is also used as a synonym for governmental officials and agencies. In this way, our whole vocabulary of power is impregnated by imageries of public administration relying on laws and chains of command.

The focus on formal hierarchies fits poorly into instances in which there are no predefined relations of dominance; where, instead, several actors struggle for their importance and influence. Since the vocabulary leads us to thinking that the struggle is over and relations of dominance are settled, attention is drawn away from the 'micro-physics' (Foucault 1977) and 'capillaries' (Foucault 2003) of power: the ways in which many persons make moves and lay claims that affect the conditions of the actors involved. Such competition between the actors is not only a starting point for a later status quo but, rather, the expected state of affairs in a well-functioning liberal economy where, it is assumed, the fundaments of social order are determined by the 'invisible hand' of the market. Consider organizational arrangements by which the state's bureaucratic norm steering has been replaced by privatization, market steering and performance-based pay, so that actors are expected to become enterprising subjects (Rose 1992, 1999). In these circumstances governance is based on defining and negotiating the rules of the game, not giving orders to the players. As to the competitors, some are always more successful than others but there are no chains of command, and assumptions about dominance or leadership are constantly contested. When all actors, even within the same organization, are 'enterprising selves' whose pay or profit depends on their performance, the organization is 'flat.'

The same flatness is evident when we look at power and governance from a global perspective. Many authoritative sources or entities appealed to in national political contexts are in fact international bodies such as intergovernmental organizations (IGOs) and international non-governmental organizations (INGOs), whose influence is based on their respect, not their ability to give orders (Alasuutari 2016). They are outside the organizational structures of national states. As to world society, it is essentially stateless; it has an 'almost feudal character of parcelized legal-rational sovereignty', as Meyer and others (1997, p. 145) put it. Yet nation-states are surprisingly similar in many dimensions and change in similar ways, but that is because they adopt 
similar policies voluntarily, not because of a world government or other hierarchical institutional order. Advances in global governance, for instance in environmental protection, are primarily based on the creation of global 'epistemic communities' (Haas 1992a, 1992b, Miller and Fox 2001) that influence public opinion and policymakers. The influence of the global organizations and networks involved depends on their respect and credibility, but the global system does not form a chain of command in which an actor or body has formal authority to give orders. ${ }^{3}$

Actors in flat organizations or networks do have authority in that their views and recommendations are respected, but such a meaning for the word authority is different from authority depicting a person who has legitimate right to give orders that are obeyed (Weber 1978, p. 53). Therefore, to better capture such strategies of power, we need to adopt the broader meaning of authority that captures very well the key role of language and signification in the social world and its power games, pointed out in discourse theories. From the discursive perspective, power is essentially the struggle for persuasion, which is in turn based on the utilization of actors, facts or principles that others take seriously.

\section{Authority as persuasion power}

Weber's classical typology of authority deals with different grounds for someone's ability to give orders that are obeyed. But dictionaries also give authority other meanings. In addition to being an attribute of a superior position, authority is commonly used to describe the confident quality of someone who knows a lot about something or who is respected or obeyed by other people. Thus, an expert or an authoritative text, such as a law or a holy text, can be called an authority. If we combine these two meanings, we can broaden the meaning of authority to depict the influence or persuasion power that an actor or text has in that others take it seriously into consideration when deciding about their views or behavior.

Generally acknowledged authorities have differing groundings, but those bases are often enmeshed into a generic epistemic capital usable in affecting others' conduct. In addition to the idea that actors can accumulate it, authority is analogous to capital in that, like money, one can invest in and lend authority. For instance, individuals invest in a politician by trusting in and supporting her, and she can use those investments in advancing political goals. Similarly, individuals 'lend their names' to political parties or associations, which appear as 'influence banks' (Parsons 1963a, p. 61), which can, in turn, reinvest that authority to promote goals that all their supporters would not necessarily approve of (Coleman 1963). Secondly, like capital, authority is a social relationship, and as such it is based on others' trust: a person or organization is influential insofar as they are considered authoritative by others. This also means that the masses of people believed to support an organization or, say, an army's ability to carry out a military strike, can be imaginary; what counts is the actor's credibility (although fooling others is seldom easy).

It is also important to stress that authority as epistemic capital is used not only by the allegedly powerful 'influence banks.' Like money, epistemic capital is in constant circulation. Actors who aim to work on the comportment of others lend others' authority by referring to them: by presenting a framing of reality that utilizes 
authoritative views and actors. Besides, authority is not only a property of actors: generally respected principles are also authorities that actors employ. But whether actors present themselves as powerful or allude to perceived authorities and authoritative principles, they struggle to impose their vision of the social world on others, hence affecting their understanding and behavior.

From this perspective, we can identify different types of reasons why someone or something is respected or feared. The reasons for such deference may range from physical strength to expertise and to a source's divine origins, but in the last instance the crucial factor is how others perceive the object of respect. In other words, authority must be considered as built on belief and trust, which can be used to manipulate others' conception of the situation at hand. This does not mean that we deny the impact of factors such as wealth and other material resources on an actor's ability to control and influence others' behavior. It only means that we must not use any features or properties as self-evident explanations for individuals' moves and social processes. In that way, we would miss an important aspect of governance: speakers construct and appeal to facts, principles or entities that they assume others consider as unavoidable determinations of the situation, or they cite sources believed to give credence to the claims and proposals made. Since the construction and employment of authority to strengthen a speaker's truth claims, rationales, propositions or commands are a means to influence others' moves, manipulation and deception are a potential part of the game.

This means that when we try to understand and explain the ways in which actors attempt to influence others' conduct, we need to analyze the way they use common understandings of how such influence occurs. The concept of authority is a case in point. Rather than originating in social science, it is a tacit concept people use to refer to persons or entities considered influential one way or another. This entails that - to use terms introduced in ethnomethodology (ten Have, 2004, p. 34-38, Zimmerman and Pollner 1971) - authority must be viewed both as a resource, i.e. as an analytical concept we use as sociologists, and as a topic that is itself in need of sociological scrutiny. As a concept commonly used in discussing power and influence in society, authority is an example of what Don Zimmerman (quoted in ten Have 2004, p. 34) calls 'idealizations'. They are a feature of social life, not only as a natural part of scientific theorizing but also in the form of commonsense typifications.

When approaching authority as a topic of social life, we could say that we adopt a nominalist view of power (Foucault 1980, p. 93, Alasuutari 2010): authority is a term by which people refer to important and influential persons, organizations, sources and other entities. People use the notion of authority as a referent that lumps together different means by and occurrences in which such influence takes place. In addition, actors use common conceptions of authority strategically as means to influence others' views and conduct.

One feature of the common concept of authority appears to be that we presuppose an organizational hierarchy in which authority comprises power possessed by those residing 'high up' in society, able to dictate what those placed lower can or must do. Consequently, actors utilize the assumption of hierarchy as one of the cultural imageries of the social world (Alasuutari and Qadir 2016). For instance, actors who want to influence national policies often attempt to create and utilize the impression that 
international governmental organizations such as the UNICEF have sanctioning power over government policies (Alasuutari et al. 2016).

Naturally, the tacit assumption that authority is based on a hierarchical position is not the only way in which actors aim to create and utilize respect for someone or something. Authority is also commonly associated with a source or entity that represents moral high ground, undisputed knowledge and expertise, the views of the majority, or strength by which to combat clashing interests. Persons aiming to create respect for an actor also utilize these images of authority. In addition, authority is typically associated with an entity bigger and more permanent than a single individual. This element of the tacit concept of authority is also utilized by people who want to influence others. In world society theory, this has been given special emphasis by saying that in modern society, actorhood has an agentic aspect: individuals act as agents for imagined general principles, often embodied in entities such as organizations and nation-states (Meyer and Jepperson 2000, Meyer 2010). Existing world society theory scholarship has stressed the consequence this has for global isomorphism: rationales of conduct become codified, standardized and naturalized, which means that they make individuals' behavior more uniform and predictable, and general moral principles also diffuse more easily. But this also has implications for strategies by which actors try to influence others' opinions and choices: it is useful to establish and act as an agent for a collective actor, such as an NGO, which claims to represent a large body of members and a set of ideals and principles. Hence actors typically claim authority for, and in the name of, an organization.

Since authority draws on beliefs about the features of authoritative entities, to influence public opinion and policymaking, actors pay attention to image management and branding (Blood 2004, Vestergaard 2008, Kylander and Stone 2012, Schwenger et al. 2014), which does not necessarily mean a conscious strategy. Such branding of organizations can take many forms. Typically, NGOs want to be perceived as professionally managed, influential formal organizations that are official guardians of a good cause or representatives of a civil society group. For instance, Hilhorst (2003, p. 7) says that nongovernmental organizations engaged in development aid or charity have a 'claim-bearing label' based on their good purposes, which enables them to make a bid to access funding and public representation. ${ }^{4}$

Of course, this does not mean that there is no foundation for authority. It is not feasible to create a credible brand of an organization without sufficient resources. For instance, to become known and respected as a knowledge-producing think tank one needs to create a track record of respectable research reports. Similarly, arranging a demonstration requires people in the street. But the public attention that an organization or event gets, the message that gets across to others and their perception, is what counts in the last instance. Authority is relational, and therefore dependent on others' recognition.

As stated, there are different reasons why actors or other components of the social world are considered authoritative and hence respected or feared. In the subsequent sections, I will discuss the four types of authority. 


\section{Capacity-based authority}

The theory of power and authority developed here differs from Arendt's (1970) and Foucault's (1982, p. 220) views, according to which violence falls beyond the strategies of power. I propose, instead, that threat and acts of violence are one source of authority: they contribute to making an actor worth taking account of when others are considering their moves. To use the term coined by Avant and others (2010, p. 13-14), such capacity-based authority can also be based on other capabilities, such as wealth; for instance, banks who can decide about loans and investments have such authority.

The reason why Arendt (1970) counts violence outside the sphere of power is that according to her - power is a property of a community. Therefore, according to this line of thought, violence destroys the legitimacy of power, which is why 'power and violence are opposites; where the one rules absolutely, the other is absent' (1970: 56).

Albeit understandable in its own context, the way such a view is blind to strategic uses of violence in innumerable contexts also illustrates the limitations of the hierarchical view of power. It is certainly true that violence is a risky last resort not only because it may weaken the effect of strategies that appeal to the subjects' loyalty. An aggressor may also be defeated by the resistance that violence raises, in which case their authority based on fear of their strength is lost. In that sense, an act of violence, for instance a war, is like a reset button: the outcome is used as an indicator that shows which is the most powerful military might, and hence it affects the future pecking order. ${ }^{5}$ Yet acts of violence are just one strategy within relations and strategies of power. Violence can be used in several ways. It can be a strategy by which an actor coerces the victims to act in a desired way. Terror, instead, is a message sent toward the rest of the target population, meant to influence its behavior. An army's military operation abroad may serve a function in the domestic political field: it is a sign of strength and a means to direct public attention away from domestic problems. Military groups' capacity for warfare, nuclear weapons in particular, is normally used as a deterrent. A military operation can also be used as a demonstration of what the army is capable of and what will happen if the actor's demands are not met.

As is the case with all types of authority, the results of a use or threat of violence are dependent on others' reactions. The targets of violence can respond to it in multiple ways: they can, for instance, choose to surrender to the violators' demands or try to resist and fight back. In any case, an actor's perceived capacity to accomplish violent acts affects others' perception of that actor. For good or bad, such an actor is taken seriously when others ponder their moves. Consider a dictator or a mafia boss: they are authorities in that they are feared and that their views and moves are anticipated and taken into account by others.

The threat or actual use of violence is just one special case of the use of capacitybased authority. Avant et al. (2010) use this term to reference authority that derives from and is justified by the task the authority is supposed to perform for a community. Here, however, the concept is used in a broader meaning. When for instance thinking about another country as a potential aggressor, we cannot say that they are respected for their perceived capacity to serve the community. Besides, like all types of authority discussed here, capacity-based authority is not only used by the actor to which it is 
attached; for instance, the ministries of defense use the threat of other countries as justification for their demands to increase military spending.

The influence of collective actors and happenings such as demonstrations, mass movements and parties are other examples of capacity-based authority. Political systems do not formally acknowledge demonstrations as a means to intervene in politics, but many examples show that a large enough crowd is taken seriously even by autocratic regimes. Such authority of masses is based on various grounds. A mass demonstration sends the signal that many people support the demands that the organizers make. It implies that the regime may not stay in power even at gunpoint, or that ordering the military to suppress the uprising would lead to bloodshed and possibly a civil war. Drastic measures against a demonstration also attract international attention and condemnation. On the other hand, mass movements indicate that their demands will collect votes in future elections, which is why political leaders take account of them.

Strikes and lockouts are yet another means to accumulate capacity-based authority; people listen to a group that may endanger their livelihood or prosperity. On the other hand, capacity-based authority is not necessarily materially grounded. Such authority also includes the ability to, say, accept or expel members of a community or to decide about the distribution of religious benefits, such as salvation. Weber (1978, p. 54-56) refers to the latter as hierocratic coercion, which is a basis for the authority of churches.

When used in the way proposed here, authority differs from the concept's standard usage in social theory, wherein authority refers to persons or objects that are respected and honored within a community. On the other hand, everyday usage of the concept of authority also recognizes authority based on disapproved means; such cases are referred to as authoritarian. In that sense, we could say that capacity-based authority can be either approved (legitimate) or questionable (illegitimate). In any case, the rationales through which actors aim to influence the comportment of others by utilizing those actors' perceived capacities are recognizable (for instance, the risk of violent confrontation or other means of coercion as a reaction to insubordination is perceived to be real).

\section{Ontological authority}

When considering debates in the contemporary world, speakers recurrently utilize respect for a text, person or organization that presents a credible picture of reality as a means to strengthen their argument. In a similar vein, Avant et al. (2010, p. 12) talk about expert (or expertise-based) authority, by which they allude to deference based on specialized knowledge. Avant and others, however, define this kind of authority narrowly as something that inheres in an actor, whereas I suggest that in practice, actors use ontological authority more broadly. Speakers may, for instance, refer to science or scientific facts to ground their arguments; expert opinion or research reports are referenced to argue what will happen if a decision is taken. To use Scott's (2014) typology of the three pillars of institutions, we could say that ontological authority leans on the cultural-cognitive pillar: on "the shared conceptions that constitute the nature of social reality and the frames through which meaning is made" (2014, p. 57). Similarly, Bourdieu writes that 'political struggle is a (practical and theoretical) cognitive struggle for the power to impose the legitimate vision of the social world' (2000, p. 185) - a struggle in which some actors and institutions have more deference than others. 
From a realist perspective, counting science, truth and reality as an authority used in the games of power may sound strange, because one could argue that facts speak for themselves. But that is precisely why ontological authority is so powerful: appealing to reality and to what is possible and feasible in the current state of affairs is influential because it appears to depoliticize decision-making by making it science-based. And of course, facts do not speak for themselves: someone needs to define them and spell out their implications. Because people have great respect for research-based knowledge, actors aiming to advance their stakeholder interests or otherwise influence decisionmaking have established a plethora of national and transnational research institutes and think tanks that lay claim to producing reliable knowledge of reality.

Paradoxically, ontological authority is at its strongest when the authorities or authoritative sources appear to be impartial regarding politics. From that perspective, there is no escape for policy experts and scientists from being part of power and governance: even neutral, innocent attempts to describe social reality and explain it can construct experts as authorities that are utilized in political argumentation. This does not mean that we need to give up on trying to honestly reach for the truth rather than for views that suit us politically, but it means that we must not fail to recognize scientific and other interpretations of reality as an object of sociological study. In other words, the science of society must comprise also science in society. For Emile Durkheim, this was a central question. Accordingly, his discussion of authority comes close to what is proposed here, when he stresses that the authority of science can only rely on 'opinion', by which he refers to public opinion and faith in science and scientists:

Opinion, eminently a social thing, is one source of authority. Indeed, the question arises whether authority is not the daughter of opinion. Some will object that science is often the antagonist of opinion, the errors of which it combats and corrects. But science can succeed in this task only if it has sufficient authority, and it can gain such authority only from opinion itself. All the scientific demonstrations in the world would have no influence if a people had no faith in science. (Durkheim 1995, p. 210)

One corollary of science representing authoritative views of reality is that actors will attempt to utilize that authority in various ways. Scientists tend to think that this kind of utilization of science is parasitic, threatening to corrode the authority of science, and that political uses of concepts, originally stemming from scientific research, misconstrue them. But, as Durkheim (1995) stresses, social scientists cannot escape to their own conceptual system, separate from popular usage of language. In fact, when talking about social science, typically scholars take concepts from ordinary language, give them a formal definition and use them to describe and explain society.

However, ontological authority does not necessarily rely on science and empirical evidence. Instead, it is part of the authority of religious communities and leaders. As Weber points out when discussing world religions, oracles are believed to reveal the truth (1978, p. 430) and priests to have special knowledge that allows them to determine dogmatic truths (p. 425, 463). As the Thomas' theorem puts it, 'if men define situations as real, they are real in their consequences' (Thomas and Thomas 1928, p. 571-572). 


\section{Moral authority}

Speakers also recurrently defend their views by alluding to commonly accepted principles or to actors or organizations which are respected for serving those principles or being knowledgeable about them. The law, judges and legal institutions are an obvious example; religious rules, priests and the church are a parallel case. Avant and others name such authority principle-based (2010, p. 13), but we may as well talk about moral authority, in that actors appeal to norms or standards regarding acceptable or desired conduct.

This usage of the concept of moral authority differs from Scott (2014), who distinguishes between regulative and normative authority. According to him, regulatory processes involve the capacity to establish rules, inspect others' conformity to them, and manipulate sanctions to influence future behavior, whereas the normative pillar rests on rules that introduce a prescriptive, evaluative, and obligatory dimension into social life. It could be argued, however, that regulative rules, such as laws, are codifications of moral principles. In that sense, the distinction between regulative and normative rules is unclear and needless.

It is of course true that moral authority is often mixed with other rationales. For instance, speakers may invoke international treaties because they assume that others consider those treaties as principles that guide us in the path of morally impeccable conduct. But rules and treaties can also be considered as hindrances that need to be circumvented to avoid potential sanctions imposed or other harm caused by the international community. The same goes for laws: in addition to formulating a commonly accepted practice, a law codifies a rule, the breaking of which gives legal authorities the capacity to punish the offender. In that sense, a reference to a principle or a law as a moral authority can be mixed with capacity-based authority that laws also have.

When talking about morality in general, we can make a distinction between moral codes and their interpretation. It is not conceivable to think of morality without generally approved principles, but everyday morality requires judgments. As Walzer stresses, 'moral argument is interpretive in character, closely resembling the work of a lawyer or judge who struggles to find meaning in a morass of conflicting laws and precedents' (Walzer 1987, p. 19). Accordingly, when utilizing moral authority to convince others of their views, people can allude not only to authoritative principles but also to authorities regarding their application: they cite an authoritative interpretation or persons respected for their expertise. For instance, legal experts' authority rests especially on their knowledge about how a law has been applied in earlier cases. That is because most courts follow the doctrine of stare decisis: they are bound by their own previous decisions in similar cases, especially by previous decisions of higher courts. Similarly, in many religions the church and its clergy are respected for their expertise or monopoly in defining the correct way to act to gain salvation or to apply holy texts to different situations. In this instance, Bourdieu talks about religious capital as the concentration of a corpus of secret knowledge. For instance, in Medieval Europe the Catholic Church, organized according to a complex ecclesiastical hierarchy, 'utilized a language almost unknown to the people and held a monopoly over access to the tools of worship, sacred texts, and, above all, sacraments' (Bourdieu 1991, p. 26). 
The moral authority of an interpretation leans not only on an individual who is cited but on an entire tradition of interpreting laws, moral codes or sacred texts, comprising numerous court decisions or, say, dogmas promulgated in the Catholic Church's magisterium meetings. An expert citing a corpus of knowledge borrows its authority, and simultaneously the judgment in question becomes part of the corpus. In defending their case, actors present their proposal as the only logical way to apply moral principles, but precedent cases and expert opinions always leave latitude for actors to promote their aspirations; referring to influential interpretations and texts is only a way to strengthen one's case, making it more difficult for others to argue for another solution. ${ }^{6}$ The globally surprisingly uniform lawmaking process is a prime example: at each stage of the legislative process - possibly including background reports, committee hearings and reports, and sessions in different chambers of the parliament actors interested in influencing the outcome engage in accumulating epistemic capital that contributes to narrowing down the range of what are commonly viewed as 'realistic options,' eventually standardizing any issue into a format where a decision can be made whether to pass a law (Alasuutari 2016, p. 146).

It is typical of struggles on the right thing to do that the moral nature of the issue is soon turned into a technical question, for instance disputes about the actual, measurable effects of a law or the correct way to interpret sacred texts. In this way, moral authority gets intermingled with ontological authority: 'the legitimate vision of the world,' as Bourdieu (1989, p. 20) puts it when talking about symbolic power.

\section{Charismatic authority}

In addition to the three types of authority discussed above, we can distinguish charismatic authority, which is attached to a person or institution even if there do not seem to be other grounds for their influence. According to Weber's definition, charisma rests 'on devotion to the exceptional sanctity, heroism or exemplary character of an individual person, and of the normative patterns or order revealed or ordained by him' (1978, p. 215). In practice, this means that a statement or act of a person is considered authoritative because special deference is attached to the individual or organization in question. Oftentimes it is, however, hard to see the exemplary character behind charisma in the modern world. Consider celebrities, who enjoy varying amounts of fame and appreciation (Alexander 2010). They may have special skills as artists, or they may have become famous for being born to a famous family. Yet they can influence public opinion in areas that have nothing to do with their skills or expertise, which is evidenced in that they may advertise products or promote different causes. ${ }^{7}$

Following Weber, it has been common in previous research and theorization to make a distinction between personal charisma and office charisma. As to the former, it is stressed that the attribution of charisma to a person requires exceptional times of crises, which is when followers may submit themselves to a desperately needed leader, believed to be endowed with supernatural or at least specifically exceptional powers or qualities (Weber 1978, p. 241, Szelenyi 2016, Reed 2013). According to Smith (2000), charisma is created by utilizing salvation narratives, the internal structure of which requires binary oppositions contrasting good and evil. Reed (2013) extends this discussion by stressing that the construction of charisma requires charismatic performances: the leader's public acts and displays create, in followers, a 
deeply affective connection to the leader, associated with his or her individual characteristics. Office charisma, on the other hand, denotes the 'reversal of genuine charisma into its exact opposite' (Weber 1978, p. 1139) by associating charisma with an office, for instance by establishing the belief that charisma is bound to blood relationship. But Weber (1978, p. 1139) also noted other instances of office charisma: 'The apostolic succession secured through episcopal ordination, the indelible charismatic qualification acquired through the priest's ordination, the king's coronation and anointment, and innumerable similar practices among primitive and civilized peoples all derive from this mode of transmission.' Shils (1965) has extended this discussion by stressing that there is, in society, a widespread disposition to attribute charismatic properties to ordinary secular roles, institutions, symbols, and strata or aggregates of persons. "The ritual surrounding the highest office, even in republics, the awe before the place where the ruler sits (as the Presidential Office in the White House, or the Kremlin, or the Élysée) testify to the ways in which high 'secular authority draws to itself from those who exercise it and from those who are its objects, the disposition to attribute charisma' (Shils 1965, p. 205).

Informed by Weber's historicist narrative of a general disenchantment of the world, the distinction between personal and office charisma has stressed the difference between the two, and romanticized 'genuine' personal charisma as 'the great revolutionary force' (Weber 1978, p. 245). Yet, when we scrutinize the discussion on how charisma is created and how it is attached to persons or organizations, it is obvious that the methods of creating and enhancing charisma are the same: they consist in constructing sacredness by utilizing myths and ritual. To create adulation toward a person or organization, one needs a good story or a whole set of narratives that tell about the protagonist's rise to fame, deeds, and fight against evil forces (Smith 2000), but to anchor the followers' respect for the hero to emotional experiences, one needs ritual plays or 'charismatic performances' (Reed 2013).

Whether we are talking about the creation of a supposedly new charismatic figure or an established organization, actors draw on the same basic story lines. One story line is to construct the hero as a strong, decisive leader and visionary or as an otherwise exceptionally talented person; Apple co-founder and former chief executive Steve Jobs is a good example (Bell and Taylor 2016). On the other hand, pop stars and other figures in the entertainment industry are marketed by utilizing the 'rags to riches' story: we learn that, say, Oprah Winfrey 'was born on the wrong side of the tracks and made it by willpower, talent and hard work' (Rojek 2012, p. 132). The same applies to politics; even though politicians may have a long career in policymaking, they can be branded as ordinary, 'inevitably flawed individuals, which gives them an 'authentic' quality contrasted with distant and aloof politicians' (Wood et al. 2016, p. 586). Similarly, a good 'brand narrative' (Timm Knudsen and Waade 2010, Dean et al. 2015) is crucial for organizations, for instance nation-states, which are branded as being modern, technologically advanced nations, combined with stories of their heroic past and depictions of their unique, 'authentic' national cultures (Aronczyk 2013, Valaskivi 2016).

These constructions of a person's or organization's charisma are made emotionally touching in public rituals. As Durkheim (1995) described it, the tacit logic of rites is that participants sanctify sacred persons or things by observing formalized rules in approaching them. ${ }^{8}$ The rule-governed modes of behaviour characteristic of rituals play out and 
construct social hierarchies (Bell 1997, p. 138-169, Bloch 1989). Whether we are talking about a rock concert or a speech by a political or business leader, there is a strict separation of roles: who can say what, who is in direct contact with the star, and how the audience can participate. Compared with those of a presidential candidate, the appearances of a president-elect are normally more formal and less spectacular, but in all cases the rules observed in such rituals contribute to creating deference for the main character.

In creating and utilizing charisma through symbolic and ritual means, actors are eclectic in that they make use of all possible symbols and things that are considered sacred among the participants. Hence, when the president of the United States takes the oath of office, the national flag will be flown, and the president will place his left hand on the Bible. As Bell (1997, p. 155-159) notes, since rituals aim to convey an air of sacredness, they often borrow elements that have been sanctified by older rituals. Actors also accumulate charisma by borrowing it from other charismatic figures and emotionally touching, symbolically powerful performances and artefacts. For example, signifying youthfulness, reform and even revolt, campaign songs have become a carefully picked, important part of U.S. presidential election campaigns, and strategists invite support from a host of film and music stars (Waldman 2003). Sacredness is contagious (Durkheim 1995), and hence charismatic authority can be amassed.

Utilizing charisma is evident, for instance, when speakers refer to a statement by an organization's leader to strengthen their argument. Consider a person holding the position of a nation's president. She has legally defined capacity-based authority to make certain decisions, but her personal charisma - which could be conceived as growing from her charismatic performances and from the trust citizens have invested in her through their vote (Coleman 1963, Parsons 1963a) - extends her influence much wider. On the other hand, the office of president and the national state have charisma, created through the constant ritual practices that sanctify the state and nation, and that office charisma is transmitted to the current president. Thus accumulated, charisma does not entirely fade away even when the president's term has ended, which is one reason why former political leaders are often hired as figureheads of organizations whose influence is entirely based on the publicity and goodwill they attract.

How much an actor's ability to influence others depends on their ability to utilize charisma, varies considerably. I suggest that the amount of charisma associated with an actor - a person or an organization - depends on how widely known they are, how trusted and respected they are, and how committed their fans or followers are. Through the publicity that they can draw to an issue, charismatic actors such as celebrities may also create public outrage that calls the attention of politicians, who want to collect political points by volunteering to act on the problem. In that sense celebrities mobilize capacity-based authority. On the other hand, their ability to generate goodwill for a cause, such as relieving suffering in a poverty-stricken country through private donations, works through charismatic and moral authority. The influence of NGOs specialized in policy advocacy is typically built on the assumption that they represent the voice and opinion of big masses, but in fact the publicity they gain precedes their public support and serves as the means to gather masses behind their cause. Charisma is therefore the starting point and key to their influence; consider Greenpeace, whose charismatic influence is very much built on the hazardous stunts they have pulled in the seas around the world. 


\section{Amassing and institutionalizing authority}

Although the theory of authority discussed here was not built to tackle hierarchical relations, it works well not only to unpack the struggle and contest for influence but also institutionalized power relations. ${ }^{9}$ The way different types of authority are evoked and employed in specific situations shows that they are entwined with each other. Forms of authority are also accumulated into generalized epistemic capital attached to actors, texts, and principles. They constitute the self-evidence of the social world that actors' attempts to advance their goals call into question knowingly or intuitively.

Consider a police patrol, the sight of which slows down traffic because the police have capacity-based authority to punish motorists for speeding. Such powers are also legitimated by the moral authority of law, enhanced with the state's charismatic authority, and by the police officer's capacity-based authority, described in the regulations that define the rights of the police and the citizens. To give a driver a ticket for speeding presupposes that the police can prove the facts - the speed limit in the location and the actual speed of the car - and in doing that they lean on their and the speed radar's ontological authority. If the case goes to court, all this will be debated: whether the police stayed within their jurisdiction, and whether the testimonies and speed radar measures are reliable proof that an offence has taken place.

The ontological authority of a video recording that shows police brutality related to the incident would no doubt change the situation. It could lead to demonstrations and riots that challenge the state's authority and monopoly of violence, perhaps creating the opportunity for the rise of a charismatic leader. The perceived capacity-based and moral authority of the masses and public opinion outraged by police brutality could lead to resignations or dismissals, court cases against the police officers, and even to changes in legislation.

This hypothetical example shows how different types of authority discussed here are entwined. That is partly because persons referred to as authorities on different grounds often know and mingle with one another. For instance, bureaucrats and experts consulted in planning and decision-making have a role in the exercise of governmental authority (Haas 1992b, Bislev et al. 2002, Carayannis et al. 2011, Cohen 2013). There are also theories of conspiracies and power elites that prepare, agree on, and manage political decisions hidden from the public eye.

On the other hand, different types of authority are enmeshed in people's minds because, linguistically, the word authority is a polyseme: a word with different but related senses. In different contexts, the meanings of authority could even be considered as separate homonyms: words that have the same spelling but different meanings. For instance, to refer to an office as a state authority is quite different from citing Max Weber as an authority. Yet these meanings inform and color each other. That is why it makes sense to talk about epistemic capital as the sum of all the grounds and means by which authority is built. Epistemic capital is like money invested in different assets such as currencies, equities and property: different sources of authority are part of an entity's total weight in people's minds. And different types of epistemic capital can also be exchanged with each other. For instance, respect and credibility built on the fame of a rock star can be exchanged with moral authority, which is evident in celebrities being used as goodwill ambassadors. 
Furthermore, common theories of power and authority frame people's understandings of the relations of dominance in society. Hence, theories of the power elite (Mills 1956), technocracy (Allen 1933, Jasanoff 1990), and network governance (Castells 2011) inform common conceptions, which means that actors aiming to affect decision-making need to pay attention to their public image. On the one hand, politicians may do their best to show that the political process is transparent, avoiding the impression that they prepare decisions in a small circle behind closed doors. On the other hand, many INGOs and IGOs, although they have little sanctioning power over government policies, 'act as if they were authorized in the strongest possible terms' (Boli and Thomas 1999: 37), creating the image of themselves as official representatives of stakeholder groups who play a key role in governance (see also Alasuutari et al. 2016). Similarly, many organizations and think tanks that are established to promote the interests of small stakeholder groups join forces with several others into meta-organizations (Ahrne and Brunsson 2008) or advocacy networks and coalitions (Stone 2001, 2002, 2004, 2008, Weible 2011) to make the claim that they represent the demands of a powerful block.

Naturally, the bases for actors' deference vary. Consider the frequencies with which international organizations are referenced in policy debates in different countries, which indicates the differences in their authority profiles (Alasuutari 2016, p. 116-129). The United Nations has a strong profile as a moral authority, although through its knowledge production it also plays a role as an ontological authority. As an expert organization, the OECD's influence leans on ontological authority, but as a reference group for member countries it also serves as a moral authority. In contrast, through its task as an organization that provides concrete economic assistance, the World Bank has a distinct profile as a capacity-based authority, although in its PR activity it obviously aims to be perceived as a consultative and hence as an ontological authority. But in aiming to enhance their credibility organizations build their authority on different grounds and cite other authoritative sources and entities.

\section{Discussion}

Power and authority are a popular topic in social research, but it has been divided into discrete fields: historical sociologists (e.g. Mann 1986, 1993, 2012a, 2012b) stress the material sources of social power; scholars in science studies and international policy analysis focus on the role of knowledge production and epistemic communities; and cultural studies scholars focus on popular culture, celebrities and charisma; etc. The framework introduced here attempts to integrate these approaches into a single theory. Rather than starting from the assumption that power is a feature of a community with a pecking order, this theory proposes that it is better to analyze the strategies by which actors aim to influence others, and that acquiring or employing authority as epistemic capital is one of the strategies with which this is done. In this instance, authority refers to actors or principles that people recognize as worth taking into consideration when deciding how to act. As exemplified in the previous section, researchers studying a specific case can organize their processing of evidence in the conceptual terms on offer here: how do actors construct and utilize capacity-based, ontological, moral, and charismatic authority in their quest for domination and political influence? What are their authority profiles like, and how do they account for the actors' influence? 
This theory owes pluralism to Weber, but the discursive and relational view grants authority in its different guises a bigger role in people's struggles for influence. By rejecting the questionable conceptual distinction made between power and authority, by recognizing ontological authority missed by Weber, and by relativizing capacity-based authority as just one type among others, I propose to have introduced a schema that better comprehends the use of authority in the social world. Since these ways of building and utilizing authority are always intertwined, it is of course possible to identify and name forms of authority in several ways, but I claim that these four are the building blocks from which strategies of power develop.

In aiming to influence others' choices and hence to affect social change, actors may of course only rely on purely logical arguments that convince others of the sensible thing to do ${ }^{10}$; this is what Habermas $(1984 \mathrm{a}, 1984 \mathrm{~b})$ means when he talks about communication free from domination. However, in actual practice persuading others always entails arguments and moves that employ people's conceptions of and beliefs in authorities.

Stressing that actors are struggling to influence others with various means, including coercion by force, likens the theory of authority presented here to the realist paradigm in international relations, which basically assumes a war of all against all (Donnelly 2008). The question is, can we talk about legitimation of authority under such conditions? If there is no established social order that links actors into a community, one could argue that there is nothing other than violence as a strategy to affect others. I stress, however, that we tend to draw too sharp a line between separate communities or societies, each having an established social order and list of values. In fact, national states are remarkably isomorphic, and even in armed conflicts governments appeal to ethical rules such as the international ban on chemical weapons. In that sense, we can talk about world society (Meyer et al. 1997). Furthermore, it is simplifying to assume that a social hierarchy is settled for good in any society or organization: even straightforward chains of command are constantly negotiated.

The way it is used here, authority denotes practically anything that actors use to influence others. An authority can be, for instance, a powerful person or organization, a belief, an account of reality, a principle, a text, or an object such as an atomic bomb. Extending authority from persons to material objects brings us close to Latour's (2005) actor-network-theory and to other posthumanist theories, which blur the boundary between human and nonhuman agents (see e.g. Schatzki et al. 2001, Barad 2003). However, nonhumans do not change the social world without human interference: an object can be considered an authority only if humans can make a move that constructs it as something to take seriously - for instance if a rock can be constructed as a potential weapon or if beliefs in a stone's sacredness are utilized.

From this perspective, the social world can be described as composed of and constituted by all the things that actors take into consideration when pursuing their projects. Depending on how important all these elements of reality are considered - that is, how much epistemic capital is attached to them, people avoid or fight obstacles and enemies, or try to bind others to pursue their projects. Thus, epistemic capital is a variable measure: actors are assumed to have varying amounts of influence on the conduct of others.

The vocabulary proposed here can also be used to account for hierarchical, zero-sum power games. People give consent to institutionalized chains of command, for instance regarding state structures. Apart from such cases, however, it is not possible or useful to 
give generalized accounts of who has power or how power works, because actors constantly struggle for position and influence, and the end results depend on the strategic situation at hand.

Epistemic capital is relational, based on recognition by others, which means that nobody can claim it for themselves or for an object one-sidedly. On the other hand, the more often an actor or principle is alluded to as an authority, the more important they become. Epistemic capital increases with use and diminishes with disuse. ${ }^{11}$

Because authority is relational, image management and branding are an inherent part of power games. And in this struggle, actors employ different imageries of the social world and notions of power, for instance by strengthening the image of themselves as powerful. In this sense, we could say that this aspect of power games is the opposite of conspiracy theories: rather than hiding their use of power, actors portray themselves as powerful as they can, because their recognition among others depends on others' beliefs. ${ }^{12}$ This is, of course, a well-known strategy for instance in warfare. ${ }^{13}$ But hiding the details of actual decision-making from the public is certainly another common strategy, typical of democracies that expect transparency of the political process.

Stressing that authority is based on beliefs and trust is timely, considering the developments that we have witnessed especially since the turn of the 21st century. From the late 20th century onward, globalization, coupled with the breakthrough of the Internet and social media, has fundamentally changed the dynamics of civic engagement and policymaking, leaving national states vulnerable to new kinds of strategy and populist actors, who construct themselves as charismatic saviors. New information and communication technology has enabled new ways of affecting political opinion formation, mobilization, advocacy, lobbying and influencing (see e.g. Bennett and Segerberg 2012). It is easier to try and win others' hearts and minds, organize virtual mass movements and networks, and construct credible, authoritative organizations feared and respected by decision-makers. These strategies by which actors can accumulate epistemic capital can also be utilized for populist leadership, in which truth is at the core of political contestation. The theory presented in this paper provides the means by which to critically investigate authority in the contemporary world.

\section{Notes}

1. In the community power debate, the 'pluralists' criticizing of the ruling-elite model (Dahl 1958, Polsby 1960) seemed to make a similar point by stressing that, as a starting point, one should not presuppose an elite that dominates a community. They ended up saying that there are several actors who affect decision-making in different issue areas. Yet the focus was on studying who the dominant actors are; power was considered as hierarchical feature of a community, even though it was questioned whether anyone at all runs a community.

2. This relational and constitutive view of power has been criticized for castrating the concept altogether; it has been argued that if power is everywhere, it is meaningless to talk about it, or about freedom as distinct from power and domination (see e.g. Lukes 2005). I argue, on the contrary, that presupposing a hierarchy of power dilutes the very essence of social order, which entails constant struggle for the control of and influence on others' behavior through working on their understandings of the situation at hand. Thus, there is constant strife of authorities (De Jouvenel 1993, p. 130, Coleman 1997) and tension between authoritative views. 
3. This view has been criticized as a trap 'where all social relationships are seen in the same relativistic light and where all - dominated and dominant alike - are subject to the same power of structural relations and so all subject to the same moral opprobrium' (Dowding 2006, p. 136).

4. In fact, the very point that an increasing number of non-profits want to call themselves NGOs rather than, say, charities or churches, is due to a recent global fashion that cherishes organization, which is why there has been a global explosion in the number of non-profits (Meyer and Bromley 2013). For instance, Zeynep Atalay (2016) shows how, over the last two decades, informal Islamic networks have been re-establishing themselves as formal NGOs and building transnational coalitions, adopting and vernacularizing the liberal civil society discourse as a strategy by which they become considered as legitimate representatives of and spokespersons for the Islamic world. On the other hand, in some cases actors want to be seen as spontaneous grassroots movements, distancing themselves from formal, bureaucratic parties or organizations. For example Schnable (2016) shows that a considerable share of American-based INGOs are small and run by amateurs and that they also want to retain an image of being anti-professional: as organizations whose fundraising is based on individual donors who prefer a direct link with recipients rather than a long 'aid chain'.

5. In her historical study of great power wars over the last 150 years, Ann Hironaka (2016) shows how, again and again, military scholars have analyzed the reasons for the victorious military, and competing military powers have then drawn lessons from the winners. According to Hironaka's study, the irony is that war technology changes quickly, and that the conclusions of wars are dependent on a number of contingent events.

6. For instance, Perelman $(1984,1968)$ stresses that a legal system must not be conceived as analogous to a mathematical or a logical system, because law cannot operate in isolation from public opinion, which changes over time. As he puts it, 'concerns of an ideological, moral, religious or political order can never be extraneous to the law, for they exercise a deep influence on the effectiveness of the system and on the manner in which rules of law are interpreted and applied' (Perelman 1984).

7. By applying Weber's definition, Kurzman et al. (2007) treat celebrities as a new kind of status group, but seem to imply that celebrity should not be seen as a type or subcategory of charismatic domination (see also Reed 2013, p. 256).

8. Accordingly, touching a charismatic person is considered as an extraordinary experience. For instance, a U.S. state representative was eager to talk about the moment Barack Obama held her hand for several moments. 'He is just electric, absolutely electric, and the kind of person you want to stand next to,' she said excitedly (Alexander 2010: 330).

9. In fact, it works better than, say, Weber's famous three-pronged categorization, according to which the claims to the legitimacy of authority may be based on rational, traditional, and charismatic grounds (Weber 1978, p. 215).Weber's typology does capture the kind of argumentation lawyers and state employees use constantly: they refer to laws and regulations. However, it takes the law for granted in that it does not recognize the rationales common beliefs in moral principles - behind considering law as a justification. However, it rules out someone's capacity to act, for instance to use force, as grounds for their authority. Besides, it does not recognize constructions of truth as a source of authority.

10. This is how Perelman (1982) defines the realm of rhetoric: it includes all other means to convince others than pure logic.

11. This is also how Putnam et al. (1993, p. 170) describe the social capital of communities.

12. I thank Risto Heiskala for this observation.

13. This phenomenon is also common in the animal world, in which many creatures defend themselves by pretending to be bigger or otherwise more dangerous than they are. 


\section{Acknowledgements}

I would like to thank Lisa Adkins, Selina Gallo-Cruz, Mark Haugaard, Risto Heiskala, Ann Hironaka, John Meyer, Ali Qadir, Francisco Ramirez, Marjaana Rautalin, Isaac Reed, the entire Tampere Research Group for Cultural and Political Sociology and the anonymous reviewers for their helpful comments and suggestions.

\section{Disclosure statement}

No potential conflict of interest was reported by the author.

\section{Funding}

This work received financial support from the Academy of Finland (Suomen akatemia) [grant numbers: 292353 and 294183].

\section{Notes on contributor}

Pertti Alasuutari, PhD, is Academy Professor at the University of Tampere, Faculty of Social Sciences. His research interests include global and transnational phenomena, media, social theory, and social research methodology. His monographs include The Synchronization of National Policies (Routledge 2016), Social Theory and Human Reality (Sage 2004), Rethinking the Media Audience (Sage 1999), An Invitation to Social Research (Sage 1998), and Researching Culture: Qualitative Method and Cultural Studies (Sage 1995).

\section{ORCID}

Pertti Alasuutari (D) http://orcid.org/0000-0003-4111-9641

\section{References}

Ahrne, G. and Brunsson, N., 2008. Meta-organizations. Cheltenham: Edward Elgar.

Alasuutari, P., 2010. The nominalist turn in theorizing power. European Journal of Cultural Studies, 13, 403-417. doi:10.1177/1367549410377579

Alasuutari, P., 2016. The synchronization of national policies: ethnography of the global tribe of moderns. London: Routledge.

Alasuutari, P. and Qadir, A., 2014. Epistemic governance: an approach to the politics of policy-making. European Journal of Cultural and Political Sociology, 1, 67-84. doi:10.1080/ 23254823.2014.887986

Alasuutari, P. and Qadir, A., 2016. Imageries of the social world in epistemic governance. International Sociology, 31, 633-652. doi:10.1177/0268580916662386

Alasuutari, P., Rautalin, M., and Syväterä, J., 2016. Organisations as epistemic capital: the case of independent children's rights institutions. International Journal of Politics, Culture, and Society, 29, 57-71. doi:10.1007/s10767-015-9205-3

Alexander, J.C., 2010. The celebrity-icon. Cultural Sociology, 4, 323-336. doi:10.1177/ 1749975510380316

Allen, R., 1933. What is technocracy? New York, NY: McGraw-Hill Book Co.

Arendt, H., 1970. On violence. New York, NY: Harcourt, Brace \& World.

Aronczyk, M., 2013. Branding the nation: the global business of national identity. Oxford: Oxford University Press. 
Atalay, Z., 2016. Vernacularization of liberal civil society by transnational Islamist NGO networks. Global Networks, 16, 391-411. doi:10.1111/glob.2016.16.issue-3

Avant, D.D., Finnemore, M., and Sell, S.K., 2010. Who governs the globe?. In: D.D. Avant, M. Finnemore and S.K. Sell, eds. Cambridge studies in international relations. Cambridge, UK; New York: Cambridge University Press, 1-31.

Barad, K., 2003. Posthumanist performativity: toward an understanding of how matter comes to matter. Signs: Journal of Women in Culture \& Society, 28, 801-831. doi:10.1086/345321

Bell, C., 1997. Ritual: perspectives and dimensions. New York: Oxford University Press.

Bell, E. and Taylor, S., 2016. Vernacular mourning and corporate memorialization in framing the death of Steve jobs. Organization, 23, 114-132. doi:10.1177/1350508415605109

Bennett, W.L. and Segerberg, A., 2012. The logic of connective action. Information, Communication \& Society, 15, 739-768. doi:10.1080/1369118X.2012.670661

Bislev, S., et al., 2002. The global diffusion of managerialism: transnational discourse communities at work. Global Society: Journal of Interdisciplinary International Relations, 16, 199. doi:10.1080/09537320220132929

Bloch, M., 1989. Ritual, history and power: selected papers in anthropology. London: Athlone Press.

Blood, R., 2004. Should NGOs be viewed as 'political corporations'? Journal of Communication Management, 9, 120-133. doi:10.1108/13632540510621353

Boli, J. and Thomas, G.M., 1999. Constructing world culture: international nongovernmental organizations since 1875. Stanford: Stanford University Press.

Bourdieu, P., 1989. Social space and symbolic power. Sociological Theory, 7, 14-25. doi:10.2307/ 202060

Bourdieu, P., 1991. Genesis and structure of the religious field. Comparative Social Research, 13, $1-44$.

Bourdieu, P., 2000. Pascalian meditations. Stanford: Stanford University Press.

Bourdieu, P. and Nice, R., 1977. Outline of a theory of practice. Cambridge: Cambridge University Press.

Carayannis, E.G., Pirzadeh, A., and Popescu, D., 2011. Institutional learning and knowledge transfer across epistemic communities: new tools of global governance. New York, NY: Springer.

Castells, M., 2011. A network theory of power. International Journal of Communication, 5, 773-787.

Chernilo, D., 2006. Social Theory's Methodological Nationalism: myth and Reality. European Journal of Social Theory, 9, 5-22. doi:10.1177/1368431006060460

Chernilo, D., 2008. Classical sociology and the Nation-State. Journal of Classical Sociology, 8, 27-43. doi:10.1177/1468795X07084693

Clegg, S., 1976. Power, theorizing, and Nihilism. Theory \& Society, 3, 65-87. doi:10.1007/ BF00158480

Cohen, N., 2013. The power of expertise? Politician-bureaucrat interactions, national budget transparency and the Israeli health care policy. Policy Studies, 34, 638-654. doi:10.1080/ 01442872.2013.804174

Coleman, J.A., 1997. Authority, power, leadership: sociological understandings. New Theology Review, 10, 31-44.

Coleman, J.S., 1963. Comment on "on the concept of influence". The Public Opinion Quarterly, 27, 63-82. doi:10.1086/267149

Dahl, R.A., 1957. The concept of power. Behavioral Science, 2, 201-215. doi:10.1002/ bs. 3830020303

Dahl, R.A., 1958. A critique of the ruling elite model. The American Political Science Review, 52, 463-469. doi:10.2307/1952327

De Jouvenel, B., 1993. On power: the natural history of its growth. Indianapolis: Liberty Fund.

Dean, D., Croft, R., and Pich, C., 2015. Toward a conceptual framework of emotional relationship marketing: an examination of two UK political parties. Journal of Political Marketing, 14, 19-34. doi:10.1080/15377857.2014.990849

Dean, M., 1999. Governmentality: power and rule in modern society. London: Sage. 
Donnelly, J., 2008. The ethics of realism. In: C. Reus-Smit and D. Snidal, eds. The Oxford handbook of international relations. Oxford: Oxford University Press, 150-162.

Dowding, K., 2006. Three-dimensional power: a discussion of steven Lukes' power: a radical view. Political Studies Review, 4, 136-145. doi:10.1111/j.1478-9299.2006.000100.x

Dowding, K., 2011. Community power debate. In: K.M. Dowding, ed. Encyclopedia of power. Thousand Oaks: SAGE, 122-126.

Durkheim, É., 1995. The elementary forms of religious life. New York, NY: The Free Press.

Emirbayer, M., 1997. Manifesto for a Relational Sociology. American Journal of Sociology, 103, 281-317. doi:10.1086/231209

Fairclough, N., 1993. Discourse and social change. Cambridge: Polity Press.

Fairclough, N., 2003. Analysing discourse: textual analysis for social research. London: Routledge.

Foucault, M., 1977. Discipline and Punish: the birth of the prison. London: Penguin Books.

Foucault, M., 1980. The history of sexuality vol. 1. An introduction. New York, NY: Vintage Books.

Foucault, M., 2003. Society must be defended: lectures at the Collège de France, 1975-76. New York: Picador.

Foucault, M., 1991. Governmentality. In: G. Burchell, C. Gordon, and P. Miller, eds. The foucault effect: studies in governmentality. Chicago: University of Chicago Press, 87-104.

Foucault, M., 1982. The subject and power. In: H.L. Dreyfus and P. Rabinow, eds. Michel foucault: beyond structuralism and hermeneutics. 2nd ed. Chicago: University of Chicago Press.

Haas, P. M., 1992a. Banning Chlorofluorocarbons: epistemic community efforts to protect stratospheric ozone. International Organization, 46, 187-224. doi:10.1017/S002081830000148X

Haas, P.M., 1992b. Introduction: epistemic Communities and International Policy Coordination. International Organization, 46, 1-35. doi:10.1017/S0020818300001442

Habermas Jr, 1984a. The theory of communicative action, volume 1: reason and the rationalization of society. Boston: Beacon Press.

Habermas Jr, 1984b. The theory of communicative action, volume 2: lifeworld and system: a critique of functionalist reason. Boston: Beacon Press.

Hilhorst, D., 2003. The real world of NGOs: discourses, diversity and development. London: Zed.

Hironaka, A., 2016. Tokens of power: rethinking war. New York, NY: Cambridge University Press.

Hunter, F., 1953. Community power structure; a study of decision makers. Chapel Hill: University of North Carolina Press.

Inda, J.X., 2005. Analytics of the modern: an introduction. In: J.X. Inda, ed. Anthropologies of modernity: foucault, governmentality, and life politics. Oxford: Blackwell, 1-20.

Jasanoff, S., 1990. The fifth branch: science advisers as policymakers. Cambridge, Mass: Harvard University Press.

Kinnunen, M., 2001. Luokiteltu sukupuoli [Classified Gender]. Tampere: Vastapaino.

Kurzman, C., et al., 2007. Celebrity status. Sociological Theory, 25, 347-367. doi:10.1111/j.14679558.2007.00313.x

Kusch, M., 1991. Foucault's Strata and fields: an investigation into archaeological and genealogical science studies. Dordrecht: Kluwer Academic.

Kylander, N. and Stone, C. (2012) The role of brand in the nonprofit sector. Stanford social innovation review. Available from: http://ssir.org/articles/entry/the_role_of_brand_in_the_ nonprofit_sector [Accessed 18 Aug 2016].

Latour, B., 2005. Reassembling the social: an introduction to actor-network-theory. Oxford: Oxford University Press.

Lukes, S., 2005. Power: a radical view. Second. Basingstoke: Palgrave Macmillan.

Mann, M., 1986. The sources of social power volume 1: a history of power from the beginning to A.D. 1760. Cambridge: Cambridge University Press.

Mann, M., 1993. The sources of social power volume 2: the rise of classes and nation-states, 17601914. Cambridge: Cambridge University Press.

Mann, M., 2012a. The sources of social power: volume 3, global empires and revolution, 1890-1945. Cambridge: Cambridge University Press. 
Mann, M., 2012b. The sources of social power. Volume 4: globalizations, 1945-2011. New York, NY: Cambridge University Press.

Meyer, J.W., et al., 1997. World society and the Nation-State. American Journal of Sociology, 103, 144-181. doi:10.1086/231174

Meyer, J.W., 2010. World society, institutional theories, and the actor. Annual Review of Sociology, 36, 1-20. doi:10.1146/annurev.soc.012809.102506

Meyer, J.W. and Bromley, P., 2013. The worldwide expansion of "organization". Sociological Theory, 31, 366-389. doi:10.1177/0735275113513264

Meyer, J.W. and Jepperson, R.L., 2000. The 'actors' of modern society: the cultural construction of social agency. Sociological Theory, 18, 100. doi:10.1111/0735-2751.00090

Miller, H.T. and Fox, C.J., 2001. The epistemic community. Administration \& Society, 32, 668-685. doi:10.1177/00953990122019613

Mills, C.W., 1956. The power elite. New York: Oxford University Press.

Parsons, T., 1963a. On the Concept of Influence. The Public Opinion Quarterly, 27, 37-62. doi:10.1086/267148

Parsons, T., 1963b. On the concept of political power. Proceedings of the American philosophical society, 107, 232-262.

Perelman, C., 1968. What is legal logic? Israel Law Review, 3, 1-6.

Perelman, C., 1982. The realm of rhetoric. Notre Dame: University of Notre Dame Press.

Perelman, C., 1984. On legal systems. Journal of Social and Biological Structures, 7, 301-305. doi:10.1016/0140-1750(84)90002-2

Polsby, N.W., 1960. How to study community power: the pluralist alternative. The Journal of Politics, 22, 474-484. doi:10.2307/2126892

Potter, J. and Wetherell, M., 1987. Discourse and social psychology: beyond attitudes and behaviour. London; Newbury Park, Calif: Sage Publications.

Putnam, R.D., 2000. Bowling alone: the collapse and revival of American community. New York: Simon \& Schuster.

Putnam, R.D., Leonardi, R., and Nanetti, R.Y., 1993. Making democracy work: civic traditions in modern Italy. Princeton: Princeton University Press.

Reed, I.A., 2013. Charismatic performance: A study of Bacon's rebellion. American Journal of Cultural Sociology, 1, 254-287. doi:10.1057/ajcs.2013.2

Reed, I.A., 2017. Chains of power and their representation. Sociological Theory, 35, 87-117. doi:10.1177/0735275117709296

Rojek, C., 2012. Fame attack: the inflation of celebrity and its consequences. London: Bloomsbury Academic.

Rose, N., 1992. Governing the enterprising self. In: P. Heelas and P. Morris, eds. The values of the enterprise culture: the moral debate. London: Routledge, 141-164.

Rose, N.S., 1999. Powers of freedom: reframing political thought. Cambridge: Cambridge University Press.

Schatzki, T.R., Knorr-Cetina, K., and Savigny, E., 2001. The practice turn in contemporary theory. London: Routledge.

Schnable, A., 2016. Amateurs without borders: the projects of anti-professional INGOs. In: The future of world society theory: World Society Mini- Conference, August 2016, University of Washington, Seattle. Available from: https://evans.uw.edu/about/news/future-world-societytheory-2016.

Schwenger, D., Straub, T., and Borzillo, S., 2014. Non-governmental organizations: strategic management for a competitive world. Journal of Business Strategy, 35, 11-19. doi:10.1108/ JBS-11-2013-0105

Scott, W.R., 2014. Institutions and organizations: ideas, Interests, and Identities. Thousand Oaks: Sage.

Selg, P., 2016a. 'The fable of the Bs': between substantialism and deep relational thinking about power. Journal of Political Power, 9, 183-205. doi:10.1080/2158379X.2016.1191163

Selg, P., 2016b. Two Faces of the "Relational Turn". PS, Political Science \& Politics, 49, 27-31. doi:10.1017/S1049096515001195 
Shils, E., 1965. Charisma, order, and status. American Sociological Review, 30, 199-213. doi:10.2307/2091564

Smith, P., 2000. Culture and charisma: outline of a theory. Acta Sociologica (Taylor \& Francis Ltd), 43, 101-111. doi:10.1177/000169930004300201

Stone, D., 2001. Think tanks, global lesson-drawing and networking social policy ideas. Global Social Policy, 1, 338-360. doi:10.1177/146801810100100304

Stone, D., 2002. Introduction: global knowledge and advocacy networks. Global Networks, 2, 1-12. doi:10.1111/glob.2002.2.issue-1

Stone, D., 2004. Transfer agents and global networks in the 'transnationalization' of policy. Journal of European Public Policy, 11, 545-566. doi:10.1080/13501760410001694291

Stone, D., 2008. Global public policy, transnational policy communities, and their networks. Policy Studies Journal, 36, 19-38. doi:10.1111/psj.2008.36.issue-1

Szelenyi, I., 2016. Weber's theory of domination and post-communist capitalisms. Theory \& Society, 45, 1-24. doi:10.1007/s11186-015-9263-6

ten Have, P, 2004. Understanding qualitative research and ethnomethodology. London: SAGE.

Thomas, W.I. and Thomas, D.S.T., 1928. The Child in America; Behavior Problems and Programs. New York: A. A. Knopf.

Timm Knudsen, B. and Waade, A.M., 2010. Re-investing authenticity: tourism, place and emotions. Buffalo: Channel View Publications.

Torfing, J., 1999. New theories of discourse: laclau, Mouffe, and Zizek. Oxford: Blackwell Publishers.

Valaskivi, K., 2016. Cool nations: media and the social imaginary of the branded country. London: Routledge.

van Dijk, T.A., 1993. Principles of critical discourse analysis. Discourse \& Society, 4, 249-283. doi:10.1177/0957926593004002006

Vestergaard, A., 2008. Humanitarian branding and the media: the case of amnesty international. Journal of Language and Politics, 7, 471-493. doi:10.1075/jlp.7.3.07ves

Waldman, T., 2003. We all want to change the world: rock and politics from Elvis to Eminem. Lanham, Md.: Taylor Trade Pub.

Walzer, M., 1987. Interpretation and social criticism. Cambridge: Harvard University Press.

Weber, M., 1978. Economy and society: an outline of interpretive sociology. Berkeley: University of California Press.

Weible, C.M., 2011. A quarter century of the advocacy coalition framework: an introduction to the special issue. Policy Studies Journal, 39, 349-360. doi:10.1111/j.1541-0072.2011.00412.x

Wetherell, M., Yates, S., and Taylor, S., 2001. Discourse theory and practice: a reader. London: Sage.

Wood, M., Corbett, J., and Flinders, M., 2016. Just like us: everyday celebrity politicians and the pursuit of popularity in an age of anti-politics. The British Journal of Politics and International Relations, 18, 581-598. doi:10.1177/1369148116632182

Zimmerman, D.H. and Pollner, M., 1971. The everyday world as a phenomenon. In: J.D. Douglas, ed. Understanding everyday life: towards a reconstruction of sociological knowledge. London: Routledge \& Kegan Paul, 80-103. 